RATIONAL FOG 



\title{
Rational Fog
}

Science and Technology in Modern War

M. SUSAN LINDEE

\author{
II \\ III \\ Harvard University Press \\ Cambridge, Massachusetts \\ London, England \\ 2020
}


Copyright (C) 2020 by the President and Fellows of Harvard College

All rights reserved

Printed in the United States of America

First printing

Jacket design: Jill Breitbarth

Jacket photograph: Tape: LICreate/E+/Getty Images; Area 51, mushroom cloud: spxChrome/E+/Getty Images

9780674250222 (EPUB)

9780674250239 (MOBI)

9780674250246 (PDF)

The Library of Congress has cataloged the printed edition as follows:

Names: Lindee, M. Susan, author.

Title: Rational fog : science and technology in modern war / M. Susan Lindee.

Description: Cambridge, Massachusetts : Harvard University Press, 2020. |

Includes bibliographical references and index.

Identifiers: LCCN 2020011117 | ISBN 9780674919181 (cloth)

Subjects: LCSH: Science - Moral and ethical aspects. | Technology-Moral and ethical aspects. | Science and state. | Technology and state. | Military researchMoral and ethical aspects. | Military weapons-Moral and ethical aspects.

Classification: LCC Q175.35 .L56 2020 | DDC 355/.07—dc23

LC record available at https://lccn.loc.gov/2020011117 
To Dot 
